Beginning at the END 



\section{Beginning at the}

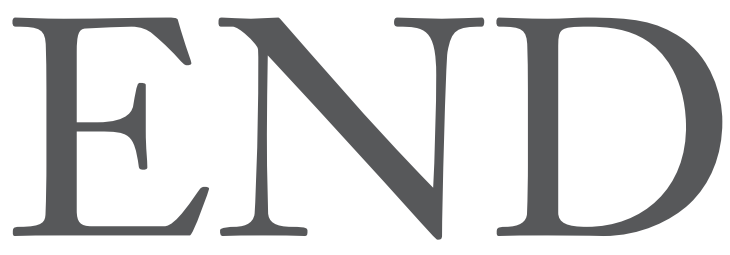

Decadence, Modernism, and Postcolonial Poetry

\section{ROBERT STILLING}

\section{Harvard University Press}

Cambridge, Massachusetts $\cdot$ London, England 2018 
Copyright (C) 2018 by the President and Fellows of Harvard College

All rights reserved

Printed in the United States of America

\section{First printing}

Library of Congress Cataloging-in-Publication Data

Names: Stilling, Robert, I977- author.

Title: Beginning at the end : decadence, modernism, and postcolonial poetry / Robert Stilling.

Description: Cambridge, Massachusetts : Harvard University Press, 2018. | Includes bibliographical references and index.

Identifiers: LCCN 2017047224 | ISBN 978067498443 I (alk. paper)

Subjects: LCSH: Decadence (Literary movement)—Developing countries. |

Postcolonialism and the arts. | Postcolonialism in literature.

Classification: LCC PN56.D45 S75 2018 | DDC 809/.91I-dc23

LC record available at https://lccn.loc.gov/2017047224

Cover photo: Un Ballo in Maschera (VI), 2004-05 (C) Yinka Shonibare MBE. All

Rights Reserved, DACS/Artimage 2017. 
For Mom, Dad, and Tom 
